\title{
FROM AN INDUSTRIAL POWERHOUSE TO A NATION OF VENDORS: OVER TWO DECADES OF ECONOMIC DECLINE AND DE-INDUSTRIALIATION IN ZIMBABWE 1990-2015
}

\author{
Alois S. Mlambo \\ [Department of Historical and Heritage Studies, University of Pretoria, South Africa]
}

\begin{abstract}
From being the second most industrialized country in Sub-Saharan Africa at independence in 1980, Zimbabwe's economy has declined rapidly to a point where the country ranks among the poorest economic performers in the region. The three pillars which had underpinned the country's vibrant economy, namely, agriculture, mining and manufacturing, have suffered greatly from poor government policy choices, resulting in the near collapse of each of the sectors and massive unemployment. As a result, an estimated 90\% of the Zimbabwean population was unemployed at 2015 and was forced to eke out a living in the informal sector, mostly through vending of second-hand clothes and other basic items. With regard to the manufacturing sector specifically, the sector had all but collapsed by 2015, as companies either folded or relocated to escape the country's harsh economic climate. This article traces the decline of the Zimbabwean manufacturing sector from 1990 to 2015 and seeks to explain the factors contributing to this decline.
\end{abstract}

\section{Introduction}

At independence in 1980, the incoming government under Robert Mugabe inherited a very thriving and diversified economy underpinned by three key economic pillars, namely agriculture, mining and manufacturing. Zimbabwe was the most industrialised country in Sub-Saharan Africa with the exception of South Africa and was a major exporter of manufactured products to its neighbours. By 2015, however, the country's industrial sector had all but collapsed following years of economic problems that resulted in serious deindustrialisation as factories closed and relocated to neighbouring countries and thousands of

\footnotetext{
${ }^{1}$ The author expresses his gratitude to all those who read and commented on this paper during its evolution and, especially, to the participants of the international symposium on "Africa and Asia Entanglements in Past and Present: Bridging between History and Development Studies", Kansai University, Osaka, Japan, 31 July - 1 August, 2015.
} 
workers were thrown out of employment. By the middle of 2015, Zimbabwe had become a nation of vendors, with an estimated $90 \%$ of its population unemployed and struggling to eke out a living in the mushrooming informal economy. After a brief discussion of the growth and performance of the sector in the colonial era and the first decade of independence, this paper traces the decline of the country's manufacturing sector ${ }^{2}$ from 1990 to 2015 and attempts to account for this decline.

\section{The colonial era to 1979}

As noted, at independence in 1980, Zimbabwe was a leading manufacturing hub, second only to South Africa in sub-Saharan Africa. The history of the early development of this sector has been recounted and analysed by numerous scholars, including, G. Arrighi Roger Riddell, Colin Stoneman, I. Phimister, A. Mlambo et al, Pangeti and Ann Seidman, (Arrighi, 1966; Phimister, 1991; Riddell, 1988.; Riddell, 1990; Stoneman, 1990; Stoneman, 1981, Mlambo, 2000; Mlambo and Phimister, 2006; Pangeti, 1996; Seidman, 1982) among others, and will be summarised very briefly here. Early Southern Rhodesia's economy was based mainly on mining and agriculture, but, gradually, a manufacturing sector emerged and grew, especially in the wake of the country's attainment of responsible government in 1923 when colonial settlers took charge of their destiny and resolved to develop the colony's economy in their own interest. In the 1930s, the colonial state began promoting the sector by, among other activities, investing in the country's iron and steel and cotton industries. Thereafter, manufacturing benefited from the de facto import substitution industrialisation imposed on the country by the Second World War and, subsequently, from access to the larger domestic market provided by the Central African Federation of the Rhodesias and Nyasaland from 1953 to 1963 (Phimister and Gwande, 2015). As a result, the country’s

\footnotetext{
${ }^{2}$ Under this label are included roughly 10 categories of manufacturing, namely, foodstuffs, beverages and tobacco, textiles, clothing and footwear, wood and furniture, paper, printing and publishing, chemicals and petroleum products, metals, non-metallic minerals, transport and transport equipment. See ZIMSTAT, 2010.
} 
manufacturing sector grew significantly to contribute 20\% to the country's GDP by 1965 (Stoneman, 1990, p. 246).

The unilateral declaration of independence (UDI) by the government of Southern Rhodesia under Prime Minister Ian Smith in 1965 brought down international economic sanctions on the government in retribution for its illegal action. This virtually imposed an import substitution industrialisation regime on the country, as it had to produce most of what it used to import to cater to the needs of the local population. In a determined effort to keep the country's economy viable, the Rhodesian government introduced a number of interventionist and protectionist policies which helped the manufacturing sector to grow and made the country almost self-sufficient in meeting its consumer goods needs (African Development Bank, 2011, p. 1). Among the policies and instruments used were "exchange and import controls, tariffs, and joint state-private ventures" and maintaining African workers' wages low in order to maximise profits (Seidman, 1982).

The close cooperation between the colonial government and local industrialists, in their joint determination to combat international sanctions, made measures such as foreign currency and import controls tolerable and effective, while necessity promoted innovation and the development of the critical skills required by the sector (Ndlela and Robinson, p. 2). As a result, the sector's contribution to GDP had risen to $25 \%$ by 1974(Stoneman, 1990, p. 247). The sector was then characterised by a growing dominance of transnational corporate capital which was channelled into the country through subsidiaries in South Africa as a sanctions-evading strategy, a focus on catering to the "luxury and semi-luxury requirements of the High-income (white) minority", and a concentration in two urban areas, namely, Salisbury (Harare), and Bulawayo, with $47 \%$ and 22\%, respectively (Seidman, 1982). Thus, while Zimbabwe inherited a highly developed and sophisticated manufacturing sector which 
was second only to South Africa in sub-Saharan Africa, it was a sector that benefited mostly the minority white population.

The colonial economy had been built on a racially inequitable basis that favoured the white settler minority at the expense of the African population. Many obstacles were crafted to keep Africans out of any meaningful participation in the country's economy except as cheap labour or petty business operators. For instance, they could not legally own land in parts of the country which were designated 'white areas', which also happened to include all urban and mining centres and areas where commercial agriculture was possible. This automatically meant that Africans could not become owners of serious manufacturing businesses, mines or commercial farms.

Secondly, colonial financial institutions would not provide loans to African entrepreneurs who were regarded as high risk and who, in any case, had no collateral. This meant that Africans could only operate small retail shops, grinding mills, tuck shops, bars, eating houses in the African townships and in the African Reserves or they became transport operators, mostly as bus owners. This is precisely the paradoxical situation of a country that had a highly sophisticated and thriving manufacturing sector, while, "most Zimbabweans cannot yet afford to buy the goods manufactures by the modern manufacturing sector". In the meantime,

[T]ransnational mines dig up and export the nation's mineral wealth, a narrowly circumscribed manufacturing sector produces luxury and semi-luxury goods for the high-income majority. These have emerged out of a century of colonial rule as prosperous enclaves in a sea of poverty (Seidman, 1982).

In effect, therefore, the incoming independence government had inherited a highly unequal economy in which the country enjoyed "one of the highest average per capita incomes in sub-Saharan Africa, but the majority of its population remains among the most 
impoverished in the world" (Seidman, 1982). The challenge was how to redress this imbalance, while maintaining the country's position as a premier manufacturing economy.

\section{The first independence decade, 1980-1990}

Notable efforts were made in the first independence years to improve the quality of life for the African majority who had been marginalised under colonialism. The rapid expansion of education and health services and the improvement of the ordinary people's access to these, the pro-worker legislation that included minimum wage regulations, among other measures, are well documented (Mlambo, 1997). With regard to the economy, in general, and the manufacturing sector, in particular, there were several uncomfortable continuities into the independence period. For instance, the industrial economy, as was also the case with commercial agriculture, remained in the hands of the white minority and their transnational corporate partners, with a few co-opted African elites in junior positions, needed mostly for facilitating access to the post-colonial ruling elite and policy makers. Thus, in the words of Brian Raftopoulos, many years into independence, "the economic structures that produced and sustained a white elite ... [were], in their essentials, still prevalent" (Raftopoulos, 2000, 713-745). Such remnant inequalities were, eventually, to lead to the development of several indigenous business lobby groups demanding a share in the country's economic cake and was, arguably, the driving force for the country's indigenisation policy in 2008 (Mlambo, 2015).

There were also continuities in government policies towards the manufacturing sector. Like its colonial predecessor, the government also employed a variety of interventionist and protectionist tools to promote economic development despite the occasional talk about the need to liberalise "foreign exchange and trade regimes" (Stoneman, 1990, p. 249). As Ndlela and Robinson note, at independence, "the new government 
maintained the panoply of controls over the economy; with the apparent intention of using state intervention to redirect development to benefit the mass of the population" (Ndlela and Robinson, p. 5). However, the measures that had worked so well under UDI because of a close relationship between the colonial state and the private sector dominated by corporate capitalism because of their confluence of interests was to become strained in the independence period in the absence of such a rapport, more so when government's pro-labour policies were seen as interfering with private capital's profits. Also, as in the colonial era, post-colonial industrial strategy was predicated, as it had been in the colonial era, on the "dominance of foreign and settler capital, the orientation towards production for an elite" and "an expanded state role", using an institution inherited from colonialism, namely, the Industrial Development Corporation (IDC) dating back to 1963, and "the balance between import substitutions and export orientation" (Stoneman, 1990, p. 248).

Despite these and other challenges, the economy, in general, and the manufacturing sector, in particular, performed well for most of the 1980s. During the 1980-82 period, the economy boomed, averaging $10 \%$ growth. Thereafter, the growth rate declined to an average of $5.5 \%$, which was still higher than the average for sub-Saharan Africa during the decade. Fuelling this economic growth was growing domestic demand, as workers' wages were increased due to government interventions, government's redistributive policies that saw a vast expansion of education and health facilities, and the opening up of external markets, among other factors (African Development Bank, p. 3). Regarding the manufacturing sector specifically, the country's picture looked very promising enough at the end of the first independence decade to lead economist Roger Riddell to write, with great optimism, that:

The story of industrialisation in Zimbabwe is undoubtedly one of success. Among the main achievements are the following: widespread and sustained expansion; a deepening of the industry structure with the development of substantial inter-linkages within manufacturing and with other sectors of the economy and the evolution of a manufacturing sector much of which appears to be internationally competitive. . . In 
spite of foreign exchange shortages, new investment in manufacturing is continuing (Riddell, 1988, p. 74).

Even more ironical in the light of the subsequent rapid decline of the country's infrastructure, was Riddell's unbounded praise for Zimbabwe's infrastructure. He commented:

Similarly, the physical infrastructure is improving while, in general, being maintained in a high degree of efficiency with the electrification of the railways system, a highly inter-connected and well maintained road system, adequate electrical power to sustain rapid and, it if were to occur, even more electrically intensive manufacturing expansion and an increasingly automatic, satellite-linked telecommunications system (Riddell, 1988, p 74).

As will be shown later, the picture in the new millennium was just the opposite of the brave new world that Riddell had foretold.

\section{The 1990s}

Manufacturing grew sluggishly in the 1990s for a variety of reasons; the main one being the negative effects of the Economic Structural Adjustment Programme (ESAP) which the Zimbabwe government started implementing in 1991. The economic reform programme was designed to revamp the economy through a raft of liberal measures that included the dismantling of price and exchange rate controls, privatisation of public enterprises, and trade liberalisation, among others (Ndlela, 2003, p. 134-135). A combination of factors conspired to render the reform programme unsuccessful, if not harmful to the Zimbabwean economy by its end. These included the weakness of the reform package itself (Mlambo, 1997), the very severe drought of 1992, and government's poor implementation of the programme. Meanwhile the removal of price controls led to escalating inflation levels and a marked decline in consumer demand (Saunders, 1996). 
Under growing economic stress, the manufacturing sector struggled, leading to some companies either downsizing or closing down. Particularly hard hit was the textile industry, which found itself having to compete with cheaper imports at a time when the economic climate was not particularly conducive. As a result the textiles sector's contribution to manufacturing output declined from $11.3 \%$ in 1985 to $7.9 \%$ in 1995, while 87 companies in the sector had closed down by 1994 (Kanyenze, 2006, p. 280). As companies under stress were forced to retrench some of their staff, with 25000 employees reportedly retrenched by 1992, the shrinking domestic market translated into weakening consumer demand, which further put a strain on the companies that remained operative. ESAP was thus deleterious to the Zimbabwean economy, in general, and to the country's manufacturing economy, in particular. Whereas ESAP was "meant to herald a new era of modernised, competitive, export-led industrialisation", the reality was that Zimbabwe's high-performing economy of the 1980s was severely damaged (Saunders, 1996, p. 8).

Other challenges facing the manufacturing sector in this period were high interest rates, inadequate infrastructure, including insufficient and expensive electricity, limited telecommunications capacity and an inefficient and inadequate railway transport system, as well as liquidity challenges. The inadequacy of the country's electricity supply system was evident in periodic load shedding that disrupted normal industry operations. The problems of insufficient infrastructural support were the result of bad management, corruption, poor maintenance and lack of investment in public companies or parastatals like the Zimbabwe Energy Supply Authority (ZESA) and the National Railways of Zimbabwe (NRZ) in the 1980s (Ndlela and Robinson, p. 2). As will be shown, the failure of such public companies was to propel the manufacturing sector into near total collapse by the second decade of the new millennium. 
Added to these challenges was the very severe drought of 1992, which virtually turned Zimbabwe from the breadbasket of southern Africa to a net importer of basic staples, especially maize, at considerable cost. Given the very close linkages between agriculture and industry that will be discussed later, the crisis in agriculture inevitably impacted negatively on the manufacturing sector. It is estimated that the 1992 drought contributed significantly to the over 9\% drop in the manufacturing sector's volume of production (Ndela and Robinson, p. 6). By 2000, manufacturing's contribution to GDP had declined to $18 \%$ from $25 \%$ at the beginning of the 90s decade (African Development Bank, p. 7).

\section{The descent into the abyss 2000 - 2015}

The economy in general

Zimbabwe's economic decline, which was a major part of what has come to be known as the Zimbabwe crisis, ${ }^{3}$ became pronounced from 2000 onwards but it can be argued that it had started in the late $90 \mathrm{~s}$ as a result of some unwise decisions by the government. Two of the most cited ones are the decision to award large unbudgeted gratuities to liberation war veterans in November 1997 and to send Zimbabwean troops into the Democratic Republic of the Congo in August 1998 to defend that country's president who was under attack from Congolese rebels. Meanwhile, under pressure from liberation war veterans who were demanding compensation for their sacrifices during the war, Mugabe unilaterally decided to award Z\$50 000 (USD 3000) and other perks to each of the country's approximately 60000 veterans. This unbudgeted subvention to the liberation war veterans triggered a $74 \%$ decline in the value of the Zimbabwean currency against the US dollar in just over 4 trading hours on November 14, 1997 in what has come to known as Black Friday (Dewa, 2013, p. 3). The country's economic decline and the rising inflation and cost of living levels sparked off the

\footnotetext{
${ }^{3}$ The crisis was also political, social and otherwise.
} 
December 1997 food riots and strikes that led government to resort to harsh measures to quell the disturbances and, arguably, contributed to the rise of the Movement for Democratic Change (MDC) opposition political formation. Then came the land invasions of 2000 , associated with the government's unplanned and rather chaotic fast-track land reform programme, which accelerated the country's precipitous economic decline which is discussed below.

Except for a brief period between 2009 and 2013 when Zimbabwe's compromise Government of National Unity (GNU) made up of the two MDCs ${ }^{4}$ and ZANU-PF was running the country, Zimbabwe's economic performance in the twenty-first century has been disastrous. The country's GDP declined consistently each year since 2000 until Zimbabwe's ranking by GDP in the Southern African Development Community (SADC) fell from its position as second only to South Africa in the late 1990s to tenth position in 2004, only managing to beat Madagascar, Swaziland, Malawi and Lesotho, which had even smaller GDPs (Zimbabwe Institute, 2007, p. 2-4). Reportedly, the cumulative decline of Zimbabwe's real GDP growth was 50\% between 2000 and 2008. Meanwhile, real per capita income fell from US\$644 in 1990 to US\$433 in 2006 and even further down to US\$338 in 2008. The country's poverty rate at 2008 was estimated at $70 \%$, up from $42 \%$ in 1995 , while unemployment was estimated at 80 per cent in 2008 (African Development Bank, 2011, p. 3) In addition, the country faced its greatest challenge in the form of unprecedented inflation which increased considerably from 2000 and reached triple figures in 2006, to then escalate into "hyperinflation in 2007 before peaking at five hundred billion per cent" at the end of 2008. Inflation was "fuelled by years of money creation to finance public expenditures and quasi-fiscal spending by the Reserve Bank of Zimbabwe (RBZ)" (African Development Bank, 2011, p. 3).

\footnotetext{
${ }^{4}$ The original MDC had split into two since its formation, with the main faction still led by its founder president Morgan Tsvangirayi, while the breakaway faction was under Welshman Ncube.
} 
The establishment of the GNU in 2009 arrested the free falling Zimbabwean economy temporarily until the controversial 2013 general elections when ZANU-PF won overwhelmingly amidst charges from the political opposition parties of widespread rigging by the governing ruling party which, then, proceeded to dispense with the coalition. The temporary recovery had owed much to the GNU's decision to adopt two key reforms in March 2009, namely, the abandonment of the now worthless local currency and the adoption of a multi-currency regime and the introduction of a cash budget system. This promoted macro-economic stability which was supportive of economic recovery and growth, with the country's untenable inflation levels a thing of the past. As a result, real GDP grew $5.7 \%$ in 2009 (African Development Bank, 2011, p. 3). By 2011 the country's growth rate had risen to $10.6 \%$, making it one of the fastest growing economies in the world (Siyakiya, 2014, p. 16). Unfortunately, the economic resuscitation period was very short, as economic decline resumed with a vengeance from 2013 onwards, as the ZANU-PF government seemed not to have any clue about how to arrest the economic meltdown.

As the economy rapidly contracted, the formal employment sector collapsed and more and more Zimbabweans resorted to the informal sector for survival. The informal sector had, of course, begun to grow during the ESAP days when retrenchments followed the difficult economic climate created by the austerity programme in the $90 \mathrm{~s}$. The result was that, the informal economy in the country was estimated at 59.4\% of GDP in the 1999/2000 fiscal year, then, regarded as the highest in Africa whose average was $42 \%$ of GDP World Bank, 2003). In November 2000, the Confederation of Zimbabwean Industries (CZI) reported that an estimated 1.7 million people were being supported by the country's informal sector (Financial Gazette, June 2002). In 2013, reportedly, 84\% of the country's employed population of 5.4 million was in informal employment, while only $11 \%$ remained in formal employment and the balance was not classified (The Standard, Zimbabwe, 04/11/2013), 
leading Kumbirai Katsande, the then president of the CZI, to observe that Zimbabwe had become a "nation of traders" (http://africanbrains.net/2013/04/19; Biti, 2014, at http://www.zimbabwesituation.com ) or, in popular parlance, a nation of vendors. Clearly by the beginning of 2015, Zimbabwe had become a predominantly informal economy country where the formal economy employed only a minor fraction of its working population.

\section{The Manufacturing Sector}

Focusing on manufacturing, 2000 marked the start of a rapid and relentless deindustrialisation process, with the volume of manufacturing falling $33 \%$ by 2005 to stand at only two thirds of the levels at independence in 1980 (Zimbabwe Institute, 2007, p. 2-4). By 2008 capacity utilisation in the manufacturing sector was a mere 10\% (Gadzikwa, 2013). As with the rest of the economy, the sector recovered following the March 2009 reforms that scrapped Zimbabwe's local currency and introduced a multi-currency regime. It grew by $10 \%$ in 2009 , with capacity utilisation rising from $10 \%$ at the beginning of the year to about of 32.3\% (Confederation of Zimbabwean Industries, 2010, p. 11). This did not mean that the sector was out of the woods, by any means, as it continued to face a number of challenges, including erratic power and water supplies, liquidity constrains, and competition from imports (African Development Bank, 2011, p. 11-12). Nevertheless, the 2010 CZI Manufacturing Sector Survey reported optimistically: "Generally, the manufacturing sector is improving though at a slower than anticipated level". Capacity utilisation had, reportedly, increased to $43.7 \%$ in the first half of that year, which was still very low but better than in the previous year. Manufacturing was then contributing 17\% to GDP (Confederation of Zimbabwean Industries, 2010, p. 12-13). After having risen to $57.2 \%$ in the first half of 2011, capacity utilisation fell to $44.2 \%$ by 2012 , prompting the CZI to observe that the manufacturing sector was in crisis. Challenges were listed as "low product demand, lack of working capital, machine breakdown, high cost of production and cost of utilities". The worst 
performing sub-sector was identified as leather and allied products, which was said to be operating at only $27.5 \%$ capacity (Confederation of Zimbabwean Industries, 2012, p. 3).

In its 2014 report, the CZI noted that the sector was undergoing "serious deindustrialisation which has reached 'catastrophic levels"” (Confederation of Zimbabwean Industries, p. 6), with 4610 companies having closed since 2011, resulting in the loss of 55000 jobs (Zimbabwe Independent 19/06/2015). Blamed, once again, were "power cuts and costs, liquidity challenges, low domestic demand", among other problems (Confederation of Zimbabwean Industries, 2014, p. 6). Most badly hit was Bulawayo, the country's industrial hub during the colonial era where most companies were located because of its proximity to Botswana and South Africa, which experienced crippling de-industrialisation in the period under review (Munyaka, 2014; Ndiweni et al, 2014; Mbira, 2015). Clearly, the manufacturing sector was hurting badly by the beginning of 2015 .

\section{Accounting for Zimbabwe's de-industrialisation}

In the light of the above, the question to be addressed is how did Zimbabwe move from being a country of considerable promise to being "low income country under stress" (Zimbabwe Institute, 2007, p. 6)? How did a country which was regarded as an industrial hub with the second highest level of industrialisation in Sub-Saharan Africa end up being dependent on the informal economy and presiding over a rapidly dying formal economy? The answer, it will be suggested, lies in a complex mix of government policies, corruption and incompetence, the privileging of political posturing in the international arena at the expense of economic development, and a variety of exogenous factors, some of which were out of Zimbabwe's control. Without question, government policies over the years contributed to the steady decline and the near-collapse of the manufacturing sector in Zimbabwe, beginning with the over-concentration on re-distributive policies in the 1980s, such as free education 
and health services, without paying enough attention to production and generating new wealth to fund such services. One of the areas to suffer because of this was the country's basic infrastructure.

\section{Crumbling infrastructure}

While resources were spent liberally on providing free education and free health, very little investment was made in public enterprises that provided key services to the economy, in general, and to the manufacturing sector, in particular. Meanwhile lack of maintenance, gross mismanagement and corruption over the years eroded public enterprises such as the Zimbabwe Electricity Supply Agency (ZESA), National Railways of Zimbabwe (NRZ), Postal and Telecommunications Corporation (PTC), Zimbabwe National Road Agency (ZINARA), and others. These enterprises were allowed to deteriorate to an extent where they simply could not discharge their mandates of providing the services essential to keep the economy functioning optimally. Not surprisingly, the failure by these key institutions to keep up their end of the bargain undermined the economy, in general, and the manufacturing sector, in particular, through erratic energy supplies, poor water supplies, and transport bottlenecks. A good example is ZESA's increasing inability to provide sufficient electrical power to enable the economy to function normally. Total supply has been far below national demand for many years and both domestic and commercial consumers have had to endure lengthy and frequent power cuts, known in Zimbabwe as load shedding.

Equally disastrous in the long run was Government's failure to maintain, let alone improve, the basic transportation infrastructure that it had inherited at independence, particularly the country's roads and railways. The country's once well-maintained transport system had become seriously inadequate by the second decade of the new millennium, with the national railway system having, virtually, collapsed. This meant that goods that used to be 
ferried around the country and to neighbouring markets by railway were now carried primarily by road, thus, hastening the deterioration of the country's road network. The government's inability to re-surface its roads resulted in potholes, damage to vehicles, and numerous traffic accidents, among other problems. It is not surprising, therefore, that poor infrastructure featured prominently in the 2012 CZI Manufacturing Survey which identified the most problematic factors negatively impacting the sector as: 1 . Power cuts and shortages; 2. Inefficient railway network within the country; 3. Water shortages; 4. Poor road infrastructure; and 5. Absence of a well-developed rail network which links the country to the ports (Confederation of Zimbabwean Industries, 2012, p. 14).

\section{The great inflation}

The poor fortunes of the Zimbabwean manufacturing sector cannot be fully appreciated without understanding the very damaging impact that the country's unprecedented high inflation in the period up to 2008 had on the sector. Various factors help account for the sharp and disastrous rise in the country's inflation between 2000 and 2008, including the controversial fast-track land reform programme and the farm invasions that accompanied it, the 2002 drought, and the ostracism of the country by some leading Western powers in response to the farm invasions and the growing anti-Western rhetoric that emanated, mainly, from prominent government officials, including the country's President. In reprise for the farm invasions, the United States passed the Zimbabwe Democracy and Economic Recovery Act (ZDERA) in 2001 enjoining the U.S. executive director of each international financial institution to oppose and vote against any extension of any loan credit, or guarantee to the Government of Zimbabwe and any cancellation or reduction of indebtedness owed by the Government of Zimbabwe to the United States or any international financial institution. 
Other contributory factors were the increasing lack of international confidence in the country as a result of the controversial elections of 2000, 2002 and 2005 as well as the contentious 2005 Murambatsvina [removing the filth] campaign which destroyed informal urban dwellings and left thousands of poor people homeless in the name of urban renewal (Mlambo, 2008, p. 8-23). In addition, the International Monetary Fund (IMF) stopped its lending facility to the country in 2002 because of the country's failure to service the huge debt that it already owed. As foreign currency reserves dwindled because of the above factors, among others, government resorted to printing money in its bid to address its budget deficit. Adding to the problem were the quasi-fiscal activities of the Reserve Bank of Zimbabwe which, together, propelled the country towards one of the highest inflation levels known in history (Bloch, 2013; Siyakiya, p. 15).

The high inflation levels depleted business' capital resources so rapidly that they could not operate normally, while inflation also drastically eroded consumers' spending power and resulted in dwindling local demand for manufactured goods. Thus, local business was caught between a rapidly declining domestic market and soaring operational costs due to inflation, among other challenges. The choice facing many companies was either to downsize or to shut down operations completely. Worse still, until the introduction of a multi-currency regime in 2009, the Reserve Bank discouraged savings by both businesses and private individuals by periodically and arbitrarily raiding bank accounts for foreign currency and compensating bank account holders with an increasingly valueless local currency. As expected this contributed to a serious liquidity crisis, resulting in banks not being able to provide businesses with investment or other capital (Bloch, 2014). As the Zimbabwe Government's Ministry of Finance and Economic Development admitted in 2014, the "shortage of long term financing has also made retooling a tall order leaving companies stuck with antiquated equipment" (Government of Zimbabwe, 2014, p. 8-9). 


\section{Indigenisation policy}

As if the liquidity challenges were not enough, the Zimbabwe Government introduced very controversial legislation designed to promote the indigenisation of businesses operating in the country, ranging from mines to manufacturing companies and other ventures. In a bid to win popularity in the run-up to the 2008 Presidential elections in which the ruling Zimbabwe African National Union-Patriotic Front (ZANU-PF) Party of Robert Mugabe was facing stiff competition from the opposition Movement for Democratic Change (MDC) under Morgan Tsvangirayi, the government enacted legislation to increase the African people's control of the economy. Signed into law on April 17 2008, but only implemented in 2010 when government passed the Indigenisation and Economic Empowerment (General) Regulations and the Indigenisation and Economic empowerment (General) Amendment, the Indigenisation and Economic Empowerment Act 14 of 2007 provided for a 51\% indigenous shareholding in all businesses with a net asset value of US\$500 000 and above (Government of Zimbabwe, 2007 and 2010).

As argued elsewhere, Zimbabwe is not the only or the first country to practice resource nationalism, as examples abound in nationalisation and/or indigenisation campaigns in newly-independent African countries such as Nigeria, Zambia, Kenya, Uganda under General Amin, the Congo since the 1960s and, indeed, post-apartheid South Africa (Mlambo, 2015, p. 45-60). Resource nationalism is also not exclusive to Africa, as resource-rich developed countries, such as the United States, Canada and Australia have also adopted "resource nationalist policies that include the blocking of Chinese investments and the tightening of fiscal regimes in the extractive sectors" (McDermott et al, 2013). In Zimbabwe's case, indigenisation policy was a response to a long-standing demand by indigenous business people for the government to redress the economic inequalities of the colonial past when the system had been so configured that only the white minority could take 
advantage of available economic opportunities. Throughout the 1990s, Black business lobby groups had been established and had actively pressured Government to level the economic playing field (Raftopoulos, 1996). While some measures to strengthen Black business had been put in place by 2000 , in the view of the Black business group, much more still needed to be done. The economic nationalism that engulfed the country during the farm invasions and fast-track land reform programme seems to have intensified the demand for similar indigenisation in the business sector and the rest of the economy. In the run-up to the 2008 general elections, therefore, the ruling party decided to tap into these long-standing resentments to push for an anti-white and pro-indigenous law that would, hopefully, win it the much-needed political support.

While the success or otherwise of such economic nationalist policies where they have been implemented is debatable, it is clear that the policy has so far proved disastrous for Zimbabwe's economy, in general, and for the manufacturing sector, in particular. This is because the legislation discouraged potential investors and made those already involved in the country's economy to adopt a wait-and-see attitude regarding the implications of the policy on their investments in the country. The apparent confusion within government as to what the policy really meant, evident in sometimes conflicting public statements by government leaders, only made the situation worse as it suggested policy inconsistency and lack of clarity which made would-be investors even more hesitant. Zimbabwe's indigenisation policy, thus, worsened the shortage of financial resources that was already crippling the local manufacturing industry, for as Zimbabwean economist John Robertson observes:

Without off shore financial support, it will be difficult for most companies in the country to recapitalize and procure new technologies. However, we are making it difficult for foreign investors to bring their money and expertise here. Unless the indigenisation policy is reversed, Zimbabwe will continue to de-industrialise (Cited in Kachembere, 2013). 
While the other negative factors discussed in this paper clearly contributed to the country's international image problem as an investment destination, there can be little doubt that the country's indigenisation policy is one of the key deterrents to would-be investors, for as one economist pointed out, investors were unlikely to be attracted to invest in a country that was reducing them "to minority shareholders in their own companies" (Bloch, 2013). The situation was not helped by periodic government interference with the market through populist price control measures designed to keep basic commodities affordable for the majority, which meant that businesses could not charge market prices for their products. That the country is regarded as a poor destination for investment is reflected in its ranking at 171 , out of 189 countries (down from $156^{\text {th }}$ in 2010 ) in the 2015 World Bank/International Finance Corporation Doing Business report and a similarly low ranking in the World Economic forum's competitiveness Index (http://www.tralac.org/bews/article/6625).

\section{Unfair and Unregulated International Competition}

Another source of problems for local industry is what the manufacturing sector identifies as an unhelpful tariff regime that favours outsiders at the expense of local producers and which gives South Africa, Zimbabwe's giant neighbour, unfair advantage. This can best be illustrated by focusing on the challenges facing the Zimbabwean Pharmaceutical industry, which is struggling as a result of the fact that the Zimbabwe Government's duty regime is "giving South African products an edge on the local market" and destroying the local pharmaceutical industry sector. The main problem is that, while Zimbabwean pharmaceutical companies exporting to South Africa, Lesotho and Swaziland have to airfreight their goods at US\$5 per kilogram because only the Oliver Reginald Tambo (ORT) International Airport in Johannesburg is the designated drugs port in South Africa, South African producers ferry their products into Zimbabwe at a mere US $\$ 0.80$ per kilogram by road through Beit Bridge on the Zimbabwe-South Africa border, which is a designated drugs port for Zimbabwe. This 
makes Zimbabwean products uncompetitive both in Zimbabwe and in the neighbouring countries of South Africa, Lesotho and Swaziland.

In addition, Zimbabwean producers have to pay duty of up to $40 \%$ and Value Added Tax (VAT) of $15 \%$ on imported raw materials and packaging materials, while foreign producers land their finished products duty free in the country. Given the fact that, approximately, 99\% of raw materials used by Zimbabwean pharmaceutical companies are imported, the import costs are crippling, especially in the face of cheaper South African and Indian products. A more equitable tariff regime would, thus, help Zimbabwean companies compete more favourably both in the domestic and foreign markets (Gadzikwa, 2013).

In general, Zimbabwean manufactures have argued that their government has not protected them enough from cheap foreign imports, most of which are being brought into the country illegally or in violation of the country's trade regulations. In a report, aptly entitled “Cheap Imports Choke Local Industry”, John Kachembere wrote:

Battery, oil, fats and textile manufacturers have been hardest hit by cheap imports, with most of the products originating outside the SADC Free Trade Area but attracting reduced duty when they should be subjected to prohibitive import rates (Kachembere, May 2014).

This unfair competition was, reportedly, undermining the viability of local manufacturers. For instance, the Chairman of the Leather and Allied Industries Federation of Zimbabwe reported in 2013 that "cheap footwear, estimated at about 3.5 million pairs and travel goods from the Far East, sometimes labelled as made in South Africa" continued to enter the country illegally. "Because of high production costs and aged equipment", local industries could not compete with such imports in the domestic market and internationally (www.intracen.org/). 
Local manufacturers complain about the widespread violation of rules of origin, "misclassification of goods when charging duty by customs officials, smuggling of goods into the country, and under-invoicing on imported products" as well as general corruption, presumably, of the Customs officials (Gadzikwa, 2013). Cheap goods from South Africa and, particularly, China were reported as severely harmful to Zimbabwean manufacturers. According to the CZI, South African producers and China accounted for almost $70 \%$ of goods imported into Zimbabwe. Increasingly,

Zimbabwean retailers rely on South African companies that manufacture soaps, detergents, cooking oil, dairy products, and other foodstuffs to beef up their stock, as local producers are struggling. Electrical and Household appliances produced by South African companies also dominate ... this category . . . . 41 per cent of the competition experienced by the local industry is emanating from South Africa, while China contributes 30 per cent" (Karombo, October 2014).

Confirming the damage to African industries caused by competition, particularly from China, with a special focus on textiles, Dhliwayo noted how the "huge influx of relatively cheap Chinese textiles and apparel has severely damaged the continent's own production capabilities and output" and how African producers have found it very difficult to "compete with the low cost alternatives, which are appealing to many low-income earners". It is argued that this is forcing local manufacturers to either shut down or downsize (Dhliwayo, www.consultancyafrica.com) .

\section{Jambanja: Land invasions and the Fast-Track Land Reform ${ }^{5}$}

It is also contended here that among the factors that have been most disruptive to the overall Zimbabwean economy and to the smooth operation of the country's manufacturing sector, in particular, are the violent farm invasions and chaotic fast-track land reform programme from 2000 onwards which were accompanied by mayhem and bloodletting from

\footnotetext{
${ }^{5}$ The term "Jambanja" can be loosely translated as mayhem, upheavals or generally disorderly conduct.
} 
some liberation war veterans and other government supporters which did untold damage to Zimbabwe's international reputation and standing (Muzondidya, 2007; Sachikonye, 2005). The negative impact of this controversial land-redistribution programme stemmed, first, from its disruption of agriculture which has traditionally been very closely linked with the manufacturing sector, both as a supplier of raw materials and as a consumer of finished products. Secondly, it earned the country a bad image which resulted in international condemnation, ostracism and sanctions by some Western countries and which, as argued above, made the country less attractive to investors. Lastly, the land reform led to the collapse of the agriculture industry which, in turn, led to the inevitable decline of the national economy as a whole and, inevitably, to the decline of the manufacturing sector. Before these aspects are explored in detail, it will be necessary to provide a very brief history of the land invasions or fast-track land reform.

As has been well documented, ${ }^{6}$ Zimbabwe's land question has been part and parcel of the country's history under European colonialism, starting with the hoisting of the British flag in Salisbury (Harare) by the Cecil John Rhodes-sponsored Pioneer Column in 1890.

\footnotetext{
${ }^{6}$ The literature on Zimbabwe's land question is vast. Among the major studies are the following: Mlambo, A.S. (July 2005). 'Land Grab or Taking Back Stolen Land: The Fast Track Land Reform Process in Zimbabwe in Historical Perspective', Compass (on-line journal) (July 2005); Moyana, H. The Political Economy of Land in Zimbabwe, (Gweru: Mambo Press, 1984); Moyo, S. The Land Question in Zimbabwe, (Harare: SAPES, 1995); Moyo, S. and P. Yeros (eds.) Reclaiming the land: The Resurgence of Rural Movements in Africa, Asia, and Latin America, (Cape Town: David Philip, 2005); Moyo, Sam and Paris Yeros, 'The Radicalised State: Zimbabwe's Interrupted Revolution', Review of African Political Economy, 34, 111(2007), 103-121; Muzondidya, James, (2007). "Jambanja: Ideological Ambiguities in the Politics of Land and Resource Ownership in Zimbabwe", Journal of Southern African Studies, 33 (2007); Nyambara, P.S. "Immigrants, 'Traditional' Leaders and the Rhodesian State: The Power of 'Communal' Land Tenure and the Politics of Land Acquisition in Gokwe, Zimbabwe, 1963-1979", Journal of Southern African Studies 27, 4 (2001), 771-91; Palmer, R. Land and Racial Domination in Rhodesia, (London: Heinemann, 1977); Palmer, R. 'Land Reform in Zimbabwe, 1980-90'. African Affairs 89 (1990), 163-81; Riddell, R. "Zimbabwe's Land Problem: The Central Issue” in W. H. Morris-Jones (ed.), From Rhodesia to Zimbabwe: Behind and Beyond Lancaster House, (New Jersey: Frank Cass, 1980), 1-13; Sachikonye, Lloyd (2005). "The Land is the Economy: Revisiting the Land Question," African Security Review 14, 3 (2005); Scoones, lan et al, Zimbabwe's Land Reform Myths and Realities, (Harare: Weaver Press, 2010); Mlambo, A. S. "This is Our Land: The Racialisation of Land in the context of the Current Zimbabwe Crisis", Journal of Developing Societies, 26, 1 (2010), 39-69; Alexander, J. The Unsettled Land: State-Making \& the Politics of Land in Zimbabwe 1893-2003, (Harare: Weaver Press, 2006).
} 
Thereafter, from the British South Africa Company government up to 1923, through the various Responsible Government regimes of Southern Rhodesia, to the Rhodesian Government of Ian smith in the UDI era from 1965 to 1979, successive colonial governments grabbed land from the African majority through various land laws, the most infamous of which were the Land Apportionment Act of 1930 and the Land Tenure Act of 1969. From the turn of the twentieth century, Africans were progressively confined to the so-called African Reserves that were strategically dotted throughout the country in a well-calculated attempt to keep African agricultural production from competing with white agriculture in the country's urban markets by making sure that they were located mostly in arid and unproductive areas far away from the country's major communication networks, such as railways and inter-city roads (Palmer, 1977; Mlambo, 2010; Mlambo, 2005).

Also well documented is the ever-present African resentment of colonial land policies which remained a source of friction between the races throughout the colonial period and, arguably, helped fuel the anti-colonial struggle that culminated in the armed struggle, as the two leading African nationalist movements, the Zimbabwe African people's Union (ZAPU) and the Zimbabwe African National Union (ZANU) took up arms to overthrow colonialism. The land question was discussed at the 1979 Lancaster House Conference which was convened by the British Government to find a lasting solution to Zimbabwe's conflict and which almost broke down because the redistribution of land which the African nationalists were demanding had not been addressed to their satisfaction. The conference was only saved from collapse when the British Government, with the assured support of the United States, promised to help fund the acquisition of land from white commercial farmers for redistribution to the needy African population (Mlambo, 2014).

While some land reform was undertaken in the first twenty years of independence, the inequality of land tenure between the two races remained an ever-present challenge, as 
various factors militated against a comprehensive and thorough land reform exercise that would put paid to the century-long problem. This created a potential dangerous situation for the future of the country by keeping alive a very sore issue that could be manipulated for political gain by the ruling party should the need ever arise and which would enable it to use the white population which hogged the land as a convenient scapegoat to blame for the country's problems and in order to mobilise the African masses behind it. Arguably, this is what occurred in 2000 when the newly-established MDC posed a serious threat to ZANU-PF hegemony and the latter needed an issue around which to mobilise support for itself (Mlambo, 2014).

The land invasions that commenced in 2000 , together with the government's fasttrack land reform programme rapidly changed Zimbabwe's land ownership structure; removing almost all white commercial farmers from the land and replacing them with African farmers. The manner in which this was done earned the country the condemnation of some Western countries which, as noted earlier, imposed targeted sanctions on some members of the Zimbabwean Government and select companies. More importantly for purposes of the current discussion, land redistribution resulted in a precipitous decline in agricultural output for a number of reasons. Many of the beneficiaries of the reform had no farming experience and some proved to be mere 'cell phone farmers', who did not run the newly-acquired farms as proper businesses by were content to direct farm activities by phone from the comfort of their city homes. The majority did not have the necessary capital to invest in essential inputs and equipment to make farming a viable business activity. Furthermore, because they did not have title deeds to this newly-acquired land, the new owners could not use their land as collateral to raise investment capital through applying for bank loans. Then, of course, matters were not helped at all by the fact that the country suffered several droughts in the period under discussion. The result was a dramatic slump in 
agricultural production that turned a country which had earlier been the breadbasket of the region into a basket case which now needed to import basic foodstuffs to feed its population.

The decline of agricultural production was well documented by Zimbabwean economist John Robertson in a study published in 2012 which shows a steep drop in, for example, the production of the staple maize crop from 2 million to a mere 600000 tonnes between 2000 and 2012 and wheat production from 300000 to 10000 tonnes between 2001 and 2012. There were similar steep declines in the production of other crops like coffee and flue-cured tobacco as well as in beef production (Robertson, www.mikecampbellfoundation.com ). According to the African Development Bank, agriculture had declined "steadily and drastically over the years" and its share in GDP fell from $22 \%$ in 2001 to a mere $10 \%$ in 2008 . This was attributed to the effects of the fast-track land reform programme, "erratic weather, limited access to finance, infrastructure bottlenecks, control, of producer and food prices, and large scale underutilisation of land". Lastly, the Bank highlighted the "lack of security of tenure" as an impediment to meaningful investment in agriculture (African Development Bank, 2011, p. 5; Mujeyi, 2010. p. 6).

With respect to the manufacturing sector, the decline in the country's agriculture was catastrophic. This is because manufacturing in Zimbabwe has traditionally been very closely linked to agriculture as both a source of raw materials and as a market for finished products. In the words of an African Development Bank study,

The manufacturing sector has always had strong linkages with the agricultural sector, with agriculture sourcing from it over half of intermediate goods, such as insecticides, stock feeds and fertilizer, while nearly half of agricultural produce is supplied to the manufacturing sector. The performance of the two sectors is, therefore, closely correlated. The collapse of agricultural activities associated with the implementation of the fast track land programme by the government had a devastating impact on the manufacturing sector in the past decade. Between 1999 and 2008, manufacturing activities experienced a cumulative decline of 92 percent (African Development Bank, 2011, p. 7). 
Clearly, therefore, once the Zimbabwean agricultural sector started ailing as a result of the unplanned and chaotic land invasions of 2000 and the hastily-implemented fast track-land reform, the decline of the country's manufacturing sector was to be expected, given the very close linkages and symbiotic relationship between the two economic sectors.

Lastly, both a cause and a result of the country's economic decline and the near collapse of the manufacturing sector is the brain drain that has bled Zimbabwe's human resources capital steadily since the late 1990s as technicians, engineers, local entrepreneurs and other skilled personnel key to the continued wellbeing and expansion of the country's economy fled both the ruling party's increasing political intolerance of dissent and its ever ready resort to violent methods of silencing opposition, as well as the plummeting economic conditions. Estimates of Zimbabweans living in exile place the total number as high as 5 million people, many of whom are professionals who would have contributed meaningfully to Zimbabwe's economy but who have been forced by various circumstances to emigrate to South Africa, Britain and other European countries, Australia, New Zealand, the United States and numerous other destinations. Given the fact that Zimbabwe's population is approximately 14 million, having such a large section of its population living in exile is a significant loss to the Zimbabwean society, in general, and to the country's economy, in particularly, especially given the quality of that exile population and its developmental potential.

\section{Conclusion}

The paper has traced the development of Zimbabwe's manufacturing sector from the early colonial days through UDI and the first two decades of independence up to 2015. It has argued that, from very small beginnings in the 1930s, the sector developed rapidly during the Second World War and the Central African Federation and expanded even more significantly 
in the UDI period when the colonial government adopted import-substitution strategies as a counter to international sanctions. In the independence period, the sector experienced some growth in the 1980s, but began a downward slide in the 1990s, partly due to the negative impact of the Economic Structural Adjustment Programme (ESAP) and partly because of some unwise decisions taken by the government which involved large expenditures that had not been budgeted for.

Thereafter, the farm invasions and fast-track land reform programme of the early 2000s precipitated a downward economic spiral that not only lead to the shrinking of the country's economy but also ushered in a period of massive levels of inflation that only ended when the government abandoned the local currency and adopted a multi-currency regime in 2009. Following a brief period of recovery which lasted until the controversial 2013 elections, the economy, once again, went into a tailspin as various challenges made company operations difficult. Among these were the decline in agricultural production, shortages and the high cost of power and water supplies, the near collapse of the country's infrastructure, such as the road and railway system, unregulated competition from South African and Chinese imports, among others, ZIDERA and other sanctions by Western countries and a shrinking domestic market. Finally, it was argued that the country's massive brain drain led to a crippling haemorrhage of its human resources capital which only compounded Zimbabwe's problems.

Because of these developments, a once highly-industrialised economy, second only to South Africa in sub-Saharan Africa, had become a nation of vendors, with extremely high levels of unemployment as a result of a near-total collapse of the formal employment sector. This has condemned the majority of Zimbabwe's people to eking out a living in the informal sector. Thus Zimbabwe had declined over the years from an industrial hub into a predominantly informal economy. 


\section{SOURCES}

African Development Bank. (2011) "From Stagnation to Recovery- Africa: Zimbabwe Report", in ADB, Infrastructure and Economic Growth in Zimbabwe. Tunisia: ADB.

Arrighi, G. (1966) “The Political Economy of Rhodesia”. New Left Review. 39, 35-65.

Bloch, Eric. "Causes of the Decline of Manufacturing" Zimbabwe Independent. April 19, 2013.

Bloch, Eric. (2014) “No Reprieve to Zim De-industrialisation”, Zimbabwe Independent, 8 August, 2014.

Confederation of Zimbabwean Industries (CZI), (2010) Manufacturing Sector Survey 2010. at www.czi.co.zw Accessed on 25/06/15.

CZI. (2012) Manufacturing Sector Survey 2012

CZI. (2014) Manufacturing Sector Survey, 2014.

Dewa, Didmus et al. (October 2013) "Industrial Decline in Zimbabwe: Gweru Post 2000Which Way Now?” World Journal of Arts, Commerce and Sciences, 1, 1, 1-13.

Dhliwayo, Rutendo. “A Continent Vs a Country: China Putting Strain on Africa's Clothing and Textile Industries", http://www.consultancyafrica.com Accessed on 25/07/15.

Financial Gazette, Harare, Zimbabwe, 12 June 2002.

Gadzikwa, Eve. (2013) "The Future of the Manufacturing Sector in Zimbabwe", Paper presented to the ICAZ 2013 Congress, Victoria Falls, 18-20 July.

Government of Zimbabwe. (2007) Indigenisation and Economic Empowerment Act 14, 2007 [14.33].

Government of Zimbabwe. (2010) Statutory Instrument Indigenisation $2 l$ of 2010 and Economic Empowerment (General) Regulations, 2010.

Government of Zimbabwe, Ministry of Finance and Economic Planning. (2014) Treasury State of the Economy Report. Harare: Ministry of Finance and Economic Planning.

Informal Employment Sustains Zimbabweans. http://africanbrains.net/2013/04/19/informalemployment-sustains-zimbabweans/ Accessed on 03/07/15.

"Informal economy is a dead economy - Biti", Zimbabwe Situation, 4 February 2014, http://www.zimbabwesituation.com Accessed on 03/07/15.

Kachembere, John. “Zim Faces Further De-Industrialisation”, Daily News, 4 January, 2013. 
Kanyenze, Godfrey. (2006) "The Textile and Clothing Industry in Zimbabwe" in: Herbert Jauch / Rudolf Traub-Merz (Eds.) The Future of the Textile and Clothing Industry in SubSaharan Africa. Bonn: Friedrich-Ebert-Stiftung.

Karombo, Tawanda. "SA producers turn up the heat on troubled Zimbabwean competitors", Business Report, 9 October, 2014.

Leather and Allied Industries Federation of Zimbabwe: 2013 Chairman's Annual Report, www.intracen.org/.../Zimbabwe\%20-20\%Leather\%20and\%20Allied\%20 Accessed on 25/02/15.

"Majority employed in informal sector - Zimstat survey" in The Standard [Zimbabwe], 04/11/2013.

Mbira, Leonard. (2015) “The De-Industrialization of Bulawayo Manufacturing Sector in Zimbabwe: Is the Capital Vacuum to Blame?" International Journal of Economics, Commerce and Management. III, 3, 1-14.

McDermott, Will et al. (9 May 2013). "Resource Nationalism in Africa Part 1: Supporting States and Mitigating Risk for Investors", Lexology, available: www.lexology.com/library/detail.aspx Accessed on 20/03/14.

Mlambo A. S. et al. (2000) A History of Manufacturing in Zimbabwe. Harare: University of Zimbabwe Publications.

Mlambo, A. S. (1997)The Economic Structural Adjustment Programme: The Case of Zimbabwe 1990-1995. Harare: UZ Publications.

Mlambo, Alois S. (2015) "Mugabe on Land, Indigenisation and Development" in Sabelo Gatsheni-Ndlovu (ed.), Mugabeism? History Politics and Power in Zimbabwe. UK: Palgrave MacMillan.

Mlambo, Alois. (2008)"Historical Antecedents to Operation Murambatsvina", in Maurice Vambe (ed.), The Hidden Dimensions of Operation Murambatsvina. Harare: Weaver Press.

Mlambo, A. S. (1997) The Economic Structural Adjustment Programme: The Case of Zimbabwe, 1990-1995. Harare: University of Zimbabwe Publications.

Mlambo, A. S. (2010) "This is Our Land: The Racialisation of Land in the context of the Current Zimbabwe Crisis", Journal of Developing Societies, 26, 1, 39-69.

Mlambo, A.S. (July 2005). 'Land Grab or Taking Back Stolen Land: The Fast Track Land Reform Process in Zimbabwe in Historical Perspective', Compass (on-line journal).

Mlambo, A. S. (2014) A History of Zimbabwe, (New York and Cambridge, UK: Cambridge University Press.

Mlambo, A. S. \& I. Phimister. (2006) "Partly Protected: Origins and Growth of colonial Zimbabwe's Textile Industry, 1890-1965”. Historia 52, 2, 145-175. 
Mujeyi, Kingstone. (2010) "Livelihoods after Land Reform in Zimbabwe: Emerging Agricultural markets and Marketing Channels within Newly Resettled Areas of Zimbabwe Working Paper 1. WWW.lalr.org.za/zimbabwe/zimbabwe-working-papers1/LALRWP.../file Accessed on 25/06/15.

Munyaka, Takudzwa (25 July 2014) "Industrial Empire Bulawayo Reduced to a Ghost Town", Mail \& Guardian.

Muzondidya, James. (2007) "Jambanja: Ideological Ambiguities in the Politics of Land and Resource Ownership in Zimbabwe”, Journal of Southern African Studies, 33, 2.

Ndiweni, Nkululeko et al. (January 2014) "Informal Economy as a Source of Livelihood in Zimbabwean Urban Areas: The Case of Bulawayo Metropolitan Province", International Journal of Scientific and Research Publications, 4.

Ndlela, Dan and Peter Robinson, Zimbabwe at http://archive.unu.edu/unupress/unupbooks/uu34eeOe.htm Accessed on 01/07/15.

Ndlela, Daniel. (2003) “Zimbabwe's Economy Since 1990” in Margaret C. Lee and Karen Colvard, Unfinished Business: The Land Crisis in Southern Africa. Pretoria: Africa Institute of South Africa, 134-35.

Palmer, R. (1977) Land and Racial Domination in Rhodesia. London: Heinemann.

Pangeti, E. S. (1996) "The State and Manufacturing Industry: A Study of the State as Regulator and Entrepreneur in Zimbabwe", PhD, University of Zimbabwe.

Phimister, I. (1991) "Secondary Industrialisation in Southern Africa: The 1948 Customs Agreement between Southern Rhodesia and South Africa". Journal of Southern African Studies. 17, 3, 430-442.

Phimister, Ian and Victor Gwande. (2015) "The State of Secondary Industry: Southern Rhodesia before and after UDI". Paper presented to the international symposium on "Africa and Asia Entanglements in Past and Present: Bridging between History and Development Studies", Kansai University, Osaka, Japan, 31 July-1 August 2015.

Raftopolous, Brian. (2000) "Zimbabwe: Race and Nationalism in a Post-Colonial State", Journal of Modern African Studies, 38, 4, 713-745.

Raftopoulos, Brian, (1996). "Fighting for control: The indigenization debate in Zimbabwe" Southern Africa Report 11. www.africafiles.org/printableversion.asp?id=3875 Accessed on $10 / 04 / 14$

Riddell, Roger. (1990) Manufacturing Africa: Performance and Prospects of Seven Countries in Sub-Saharan Africa. London and Portsmouth: Overseas Development Institute, James Currey and Heinemann.

Riddell, Roger. (1988) Industrialisation in Sub-Saharan Africa Country Case StudyZimbabwe [Working Paper]. London: Overseas Development Institute. 
Robertson, John. Land Reform and Its Economic Impact - Graphs, http://www.mikecampbellfoundation.com/page/land-reform-and-its-economic-impact-graphs Accessed on 20/06/15.

Sachikonye, Lloyd. (2005) "The Land is the Economy: Revisiting the Land Question," African Security Review 14, 3.

Saunders, Richard. (1996) “Zimbabwe: ESAP's Fables II” in Southern Africa Report, Vol. 11, No. 4.

Seidman, Ann. (1982) “A Development Strategy for Zimbabwe”, Zambezia, X, (i), 13-27.

Siyakiya, Puruweti. "An Analysis of the Effects of Hyperinflation on Manufacturing Sector Output. A Case of Zimbabwe's Manufacturing Forms 2000-2013”. MA dissertation submitted to Erasmus University, the Hague, Netherlands in 2014.

Stoneman, Colin. (1990) “The Industrialisation of Zimbabwe- Past, present and Future". Afrika Focus, 6, 3-4.

Stoneman, Colin (ed.) (1981) Zimbabwe’s Inheritance. New York: St. Martins Press.

World Bank. (2003) "The Informal Economy: Large and Growing in Most Developing Countries”(Moderated by Simeon Djankov), Online Discussions, Archived June 2003

Zimbabwe Independent, 19/06/2015.

"Zim Ponders the Struggle to Industrialise", Tralac Trade Law Centre, http://www.tralac.org/news/article/6625-Zim-ponders-the-struggle-to-industrialise.html Accessed on 20/03/15.

Zimbabwe Institute. (2007) Progressive Zimbabwe - Sustainable Growth and Transformation. Cape Town: Zimbabwe Institute. 